\title{
Effects of replacing fish oil with palm oil in diets of Nile tilapia (Oreochromis niloticus) on muscle biochemical composition, enzyme activities, and mRNA expression of growth-related genes
}

Christian Larbi Ayisi ${ }^{1,2,3,4,5}$, Jinliang Zhao ${ }^{1,2,3^{*}}$, Chen Yame ${ }^{1,2,3}$, Andrews Apraku ${ }^{1}$ and Grace Debra ${ }^{4,5}$

\begin{abstract}
Background: Due to the continuous demand for fish coupled with decline in capture fisheries, there is the need to increase aquaculture production to meet the demand. Aquaculture is faced with high cost of feeding since fish oil and fish meal are expensive. In view of this, there are calls to explore alternatives that are cheap and reliable.

Objectives: This study on Oreochromis niloticus was conducted to evaluate the effects of replacing fish oil (FO) with palm oil (PO) at 0\%, 25\%,50\%,75\%, and 100\% on muscle fatty acid and proximate composition as well as growthrelated enzyme activities and mRNA expression.

Methods: Oreochromis niloticus were fed five experimental diets (33\% crude protein and $10 \%$ crude lipid) for 8 weeks. Feed had variation in fish oil and palm oil contents. After the 8 weeks feeding trial, five fish were sampled from each tank (15 from each treatment) and euthanized using an excess dose of tricaine methane sulfonate (MS222 at $200 \mathrm{mg} / \mathrm{L}$ ). Fatty acid and enzyme activities were analyzed using standard protocols. Also, RT-qPCR was used to quantify the expression levels of selected growth-related genes.
\end{abstract}

Results: Fish fed 25\% PO recorded the least muscle protein content and was significantly lower than the group fed 100\% PO. Paired box protein 7 (Pax-7) enzyme activity was significantly higher in the group fed 50\% PO compared to the groups fed 25\% PO and 100\% PO, while caplain-3 (Capn-3) was significantly lower in the group fed 0\% PO compared to all other groups. There was a significant difference among treatments with respect to mRNA expression of Pax-7 and Capn-3. Group fed 25\% PO had significantly lower mRNA expression of Pax-7, while the group fed 75\% PO recorded significantly higher mRNA expression of Capn-3 compared to groups fed 0\% PO, 25\% $\mathrm{PO}$, and 100\% PO. Pearson's correlation analysis revealed that Igf-I and Igf-II mRNA expression have significant correlation with n-3 polyunsaturated fatty acids content in muscle.

Conclusion: The results suggest muscle protein content could be modified if FO is replaced with PO. Also, mRNA expression of Pax-7 and Capn-3 is affected by replacing FO with PO.

Keywords: Activity, Gene expression, Growth regulation factor, Hyperplasia, Hypertrophy, Muscle growth, Nile tilapia, Palm oil

\footnotetext{
* Correspondence: jlzhao@shou.edu.cn

${ }^{1}$ Key Laboratory of Freshwater Fishery Germplasm Resources, Ministry of

Agriculture, Shanghai Ocean University, 999 Huchenghuan Road, Shanghai

201306, China

${ }^{2}$ Centre for Research on Environmental Ecology and Fish Nutrition, Ministry

of Agriculture, Shanghai Ocean University, Shanghai, China

Full list of author information is available at the end of the article
}

(c) The Author(s). 2019 Open Access This article is distributed under the terms of the Creative Commons Attribution 4.0 International License (http://creativecommons.org/licenses/by/4.0/), which permits unrestricted use, distribution, and reproduction in any medium, provided you give appropriate credit to the original author(s) and the source, provide a link to the Creative Commons license, and indicate if changes were made. The Creative Commons Public Domain Dedication waiver (http://creativecommons.org/publicdomain/zero/1.0/) applies to the data made available in this article, unless otherwise stated. 


\section{Introduction}

Dietary vegetable oils are used as feeding material to replace the fish oil due to their abundance and relatively cheaper prices. Several studies have reported that replacing fish oil with vegetable oils enhances growth performance as reported in Atlantic salmon (Menoyo et al. 2005) and tilapia (Apraku et al. 2017) while others have documented a change in fatty acid composition ( $\mathrm{Li}$ et al. 2015, 2016). Lipids are reported to spare protein in several fish species such as grass carp and tilapia (Gao et al. 2011). However, less attention has been given to the effects replacement of fish oil with vegetable oils have on genes involved in muscle development which leads to growth.

The entire body of fish is composed of approximately $40-60 \%$ skeletal muscle. Fish have the ability to recruit new muscle fibers throughout their life time. Muscle growth progress by hypertrophy and hyperplasia which might be modulated by nutrition. Muscle growth is also controlled by several genetic factors such as growth hormone (GH), insulin-like growth factors (Igfs), and paired box proteins (Paxs) (Johnston et al. 2008). Signaling by these factors affects the balance between anabolic and catabolic processes within muscle, whereas growth occurs when protein synthesis outweighs degradation. $\mathrm{GH}$ stimulates muscle growth in fish by inducing proliferation of myogenin cells and muscle hyperplasia and/or hypertrophy. IGFs are peptides structurally related to insulin that include IGF-1 and IGF-2 (Duan et al. 2010) and directly stimulate muscle cell proliferation, differentiation, and hypertrophy and inhibit muscle atrophy. Igf$\mathrm{I}$ is the major anabolic agent responsible for tissue growth in mammals and teleost fish, and alteration in Igf-I gene expression can partly account for changes in growth rate induced by feed intake (Duan 1998). Pax-7 gene is a powerful regulator of muscle progenitors and satellite cells that contributes to the proliferation of myogenic cells during the secondary myogenesis in fish. Therefore, all of these genes act as a positive regulator of muscle growth that promotes hyperplasic and/or hypertrophic muscular growth.

In addition, muscle growth mechanisms are regulated by the sequential expression of the myogenic regulatory factors family, which includes MyoD and myogenic (MyoG) (Asaduzzaman et al. 2011). MyoD regulate the activation and proliferation of satellite cells towards a myogenin lineage, whereas myogenin act on cell differentiation and fusion of myoblasts to form myofibers (Watabe 2001). During muscle growth, the expression of MyoD and myogenin is related to hyperplasia and hypertrophy processes (Johansen and Overturf 2006).

Gene expression has been used to give a clear understanding of the genomic and molecular responses in fish nutrition (Campos et al. 2010). This study was conducted to assess the effects of replacing fish oil (FO) with crude palm oil (PO) as a feeding material on muscle biochemical composition, enzyme activities, and muscle growthrelated genes. This will provide an insight into the role of nutrient sensing by satellite cells towards myocyte differentiation.

\section{Materials and methods}

\section{Feed and feeding trial}

Five diets with identical protein (33\% crude protein) and lipid (10\% crude lipid) were used for this study. Ingredients were purchased from Nonghao Feed Company located in Shanghai, China. The diets were formulated to differ in their FO and PO composition (Table 1). Whereas FO and PO were the lipid sources, soybean meal, rapeseed meal, and fish meal were the protein sources. The progressive enlargement method was used to mix the ingredients. In brief, the dry ingredients were mixed first using a Hobart mixer. FO and PO were subsequently mixed to the homogenized dry ingredients. The mixture was subsequently pelletized using a meat

Table 1 Formulation and proximate composition of experimental diets ( $\mathrm{g} \mathrm{kg}^{-1}$ dry weight)

\begin{tabular}{|c|c|c|c|c|c|}
\hline \multirow[t]{2}{*}{ Ingredients } & \multicolumn{5}{|c|}{ Experimental diets } \\
\hline & PO 0 & PO 25 & PO 50 & PO 75 & PO 100 \\
\hline Fish meal* & 60 & 60 & 60 & 60 & 60 \\
\hline Soybean meal* & 300 & 300 & 300 & 300 & 300 \\
\hline Wheat meal* & 225 & 225 & 225 & 225 & 225 \\
\hline Rapeseed meal* & 300 & 300 & 300 & 300 & 300 \\
\hline Fish oil* & 60 & 45 & 30 & 15 & 0 \\
\hline Palm oil* & 0 & 15 & 30 & 45 & 60 \\
\hline Soybean phospholipid* & 25 & 25 & 25 & 25 & 25 \\
\hline Mineral mix** & 5.5 & 5.5 & 5.5 & 5.5 & 5.5 \\
\hline Vitamin mix*** & 4 & 4 & 4 & 4 & 4 \\
\hline $\mathrm{Ca}\left(\mathrm{H}_{2} \mathrm{PO}_{4}\right)$ & 15 & 15 & 15 & 15 & 15 \\
\hline Choline chloride & 5 & 5 & 5 & 5 & 5 \\
\hline Inositol & 0.5 & 0.5 & 0.5 & 0.5 & 0.5 \\
\hline \multicolumn{6}{|l|}{ Proximate composition } \\
\hline Moisture (g/kg) & 103 & 105.3 & 108.2 & 107 & 105 \\
\hline Crude protein (dry mass) & 331.8 & 331.5 & 330.9 & 332.3 & 331.7 \\
\hline Lipid (g/kg)(dry mass) & 98.2 & 98.1 & 98.7 & 98.8 & 98.5 \\
\hline Ash (g/kg)(dry mass) & 52.5 & 56 & 55.3 & 54 & 55 \\
\hline
\end{tabular}

*Fish meal, soybean meal, wheat meal, soybean phospholipase, palm oil, vitamin premix, mineral mix, and $\mathrm{Ca}\left(\mathrm{H}_{2} \mathrm{PO}_{4}\right)$ were supplied by Nonghao Feed Company (Shanghai, China)

**Mineral mix (mg kg${ }^{-1}$ dry diet): $\mathrm{Cu}\left(\mathrm{CuSO}_{4}\right), 2.0 ; \mathrm{Zn}\left(\mathrm{ZnSO}_{4}\right), 34.4 ; \mathrm{Mn}$ $\left(\mathrm{MnSO}_{4}\right), 6.2 ; \mathrm{Fe}\left(\mathrm{FeSO}_{4}\right), 21.1$; $\left(\mathrm{Ca}\left(\mathrm{IO}_{3}\right)_{2}\right), 1.63$; $\mathrm{Se}\left(\mathrm{Na}_{2} \mathrm{SeO}_{3}\right), 0.18$; $\mathrm{Co}\left(\mathrm{CoCl}_{2}\right)$, $0.24 ; \mathrm{Mg}\left(\mathrm{MgSO}_{4} \cdot \mathrm{H}_{2} \mathrm{O}\right), 52.7$

***Vitamin premix (IU or $\mathrm{mg} \mathrm{kg}^{-1}$ diet): vitamin A, 16,000 IU; vitamin D, 8000

IU; vitamin K, 14.72; thiamin, 17.8; riboflavin, 48; pyridoxine, 29.52;

cynocobalamine, 0.24 ; tocopherols acetate, 160; ascorbic acid (35\%), 800; niacinamide, 79.2; calcium-D-pantothenate,73.6; folic acid, 6.4; biotin, 0.64; L-carnitine, 100 
mincer with a $1-\mathrm{mm}$ die. The pellets were then dried and stored until use. The fatty acid composition of the diets is shown in Table 2.

\section{Ethics statement}

The fish were anesthetized with an excess dose of tricaine methane sulfonate MS-222 at $200 \mathrm{mg} / \mathrm{L}$ to reduce stress and suffering. The standard operation procedure as stipulated in Shanghai Ocean University's guide for the use of animals for experiment was followed.

\section{Experimental procedures}

Fingerlings of Nile tilapia (mixed-sex) with an initial weight of $9.34 \pm 0.02 \mathrm{~g}$ were collected from Shanghai Ocean University's (SHOU) tilapia germplasm station. They were then transported to an aquarium system of SHOU where they were fed two times daily with a commercial diet (30\% crude protein) purchased from Shanghai Jin Yuan Trade. Fingerlings were distributed randomly into 15 tanks at a stocking density of 40 fish per tank with water in each tank kept at $210 \mathrm{~L}$ throughout the trial. Each group/treatment comprising three tanks was fed one of the five experimental diets for

Table 2 Main fatty acid compositions of experimental diets (g/ kg total fatty acids)

\begin{tabular}{|c|c|c|c|c|c|}
\hline \multirow[t]{2}{*}{ Fatty acids } & \multicolumn{5}{|c|}{ Experimental diets } \\
\hline & $\mathrm{PO} 0$ & PO 25 & PO 50 & PO 75 & PO 100 \\
\hline $12: 0$ & 1.5 & 1.4 & 1.2 & 1.2 & 1.1 \\
\hline $14: 0$ & 55.4 & 45.2 & 32 & 22.5 & 12.7 \\
\hline $16: 0$ & 238.8 & 259 & 270 & 280.6 & 291.9 \\
\hline $18: 0$ & 53.1 & 57.6 & 54.3 & 53 & 51.5 \\
\hline$\sum$ SFA'S & 348.8 & 36.32 & 357.5 & 357.3 & 357.2 \\
\hline $16: 1(n-7)$ & 60.2 & 52.3 & 31.5 & 20.6 & 8.9 \\
\hline $18: 1(n-9)$ & 235.6 & 254.2 & 284 & 311.6 & 337.7 \\
\hline$\Sigma$ MUFAs & 295.8 & 306.5 & 315.5 & 332.2 & 346.6 \\
\hline $18: 2(n-6)$ & 206.5 & 215.7 & 230.7 & 236.2 & 243.3 \\
\hline 20:4(n-6)ARA & 5.6 & 4.7 & 4.1 & 2.5 & 2 \\
\hline$\sum n-6$ & 212.1 & 220.4 & 234.8 & 238.7 & 245.3 \\
\hline $18: 3(n-3)$ & 55.2 & 39.6 & 39.8 & 37.9 & 36.3 \\
\hline $18: 4(n-3)$ & 3.2 & 3.3 & 3.2 & 3 & 2.9 \\
\hline $20: 5(n-3) E P A$ & 42.5 & 31.9 & 22 & 14.1 & 6.2 \\
\hline $22: 6(n-3) D H A$ & 56.6 & 41.5 & 28.5 & 16.9 & 5.8 \\
\hline$\sum n-3$ & 157.5 & 116.3 & 93.5 & 71.9 & 51.2 \\
\hline DHAVEPA & 13.3 & 13 & 12.9 & 11.9 & 9.3 \\
\hline$\Sigma$ PUFAs & 349.6 & 336.7 & 328.3 & 310.6 & 296.5 \\
\hline$\Sigma S F A / \Sigma$ PUFA & 8.7 & 10.7 & 10.8 & 11.5 & 12.0 \\
\hline$\Sigma n-3 / \Sigma n-6$ & 7.4 & 5.2 & 3.9 & 3 & 2 \\
\hline
\end{tabular}

ARA arachidonic acid, EPA eicosapentaenoic acid, DHA docosahexaenoic acid, SFA saturated fatty acids, MUFA monounsaturated fatty acid, PUFA polyunsaturated fatty acid
8 weeks, two times a day at 08:00 and 16:00 to apparent satiation. Nitrite-N and ammonia-N contents of the culturing water were measured once a week using standard protocols (APHA 1998). Dissolved oxygen, $\mathrm{pH}$, and temperature were monitored on a daily basis using the YSI instrument (YSI, Yellow Spring, Ohio).

\section{Sample collection}

Feeding was stopped $24 \mathrm{~h}$ prior to sampling. Five fish were sampled from each tank (15 from each treatment) and euthanized using an excess dose of tricaine methane sulfonate (MS-222 at $200 \mathrm{mg} / \mathrm{L}$ ) (Ayisi et al. 2017).

\section{Fatty acid analysis of experimental diets and muscle}

All samples (experimental diets and muscle) were grinded into fine powder and homogenized. Total lipid was extracted using chloroform and methanol in a ratio of 2:1 (v/v) (Folch et al. 1957). Fatty acid methyl esters were prepared by transesterification using $0.4 \mathrm{M} \mathrm{KOH}$ methanol. Gas chromatography (GC-7890A) was used to detect the individual fatty acids using methyl heneicosanoate $(\mathrm{C} 21: 0)$ as an internal standard. The peak times of the detected fatty acids (samples) were compared to that of the manufacturers. Fatty acids are presented as grams per kilogram of total fatty acids.

\section{Assay of enzyme activities}

A commercial kit was purchased from Shanghai Ding Biological Technology Company Limited (Shanghai, China) to analyze enzyme activities of Pax-7, Capn-3, Igf I, Igf II, GH, Psma- $\alpha 5$, MyoD, and MyoG using enzymelinked immunosorbent assay (ELISA). A glass homogenizer was used to homogenize about $0.5-1.0 \mathrm{~g}$ of the sample and subsequently centrifuged at $4{ }^{\circ} \mathrm{C}$ for 50 $\min$ at $2500 \mathrm{~g}$. The clear phase between the pellets and top layer was used for the analysis. The optical density (OD) of each sample in 96-well plate was measured at $450 \mathrm{~nm}$. The moles of substrate converted to product per minute at assay temperature defined an enzyme activity unit (IU).

\section{RNA extraction and real-time quantitative polymerase chain reaction ( $\mathrm{RT}-\mathrm{qPCR})$}

Measurements of mRNA expression of target genes (Pax-7, Capn-3, Igf I, Igf II, GH, Psm- $\alpha 5$, MyoD, and MyoG) were performed using real-time PCR. Total RNA was extracted using Trizol reagent (Invitrogen). The RNA concentration was determined using absorbance measurements. Samples were then transcribed to cDNA and stored at $-20^{\circ} \mathrm{C}$ until analysis. Reactions were performed using a mini option real-time PCR machine (Bio-Rad) (Ayisi and Zhao 2017). Primers of both target genes and reference gene (beta-actin) used for the realtime PCR are shown in Table 3. 
Table 3 Nucleotide sequences of the primers used to assay gene expression by real-time PCR

\begin{tabular}{|c|c|c|c|}
\hline Target genes & Forward $\left(5^{\prime}-3^{\prime}\right)$ & Reverse $\left(5^{\prime}-3^{\prime}\right)$ & GenBank accession no. \\
\hline Pax-7 & TCCAGCTCGTCTATCTGCAG & TAAACAGGTCTGAGGCTGGG & XM_005459001.3 \\
\hline $\lg f-1$ & СACCCTCTCACTACTGCTGT & CACAGTACATCTCAAGGCGC & EU272149.1 \\
\hline $\mid g f-\|$ & TGTTCCGTAGCTGTGACCT & ACTTCACGGTCACATGTTGC & EU272150.1 \\
\hline $\mathrm{GH}$ & CTGGTTGAGTCCTGGGAGTT & CAGGTGGTTAGTCGCATTGG & КТ387598.1 \\
\hline Psna-a 5 & TGTCTGGCTGTGGAGAAGAG & АTCTTCCTCCCCAAACTGCA & XM_003441520.3 \\
\hline Capn-3 & TCCAGTTCTGGCGTTATGGT & CCACCAGTGAAGTCCTCCAT & XM_005477402.2 \\
\hline MyoD & GCCGGATATCTCTITCCCCA & AGGAAGGGGAGGATGAGGAT & FJ907953.1 \\
\hline MyoG & TCCTAGGGAAGCTGGGATCT & CGGTACCTGTCACTCCAACT & NM_001279526.1 \\
\hline$\beta$-Actin & TAATAACAGAACGCAGCGCC & AGTGCGGCGATTTCATCTTC & EU887951.1 \\
\hline
\end{tabular}

PAX 7 paired box protein 7, Igf-I insulin-like growth factor-I, Igf-II insulin-like growth factor-Il, GH growth hormone, Psma- 5 proteasome subunit alpha type-5, CAPN-3 caplain-3, MyoD myoblast determination protein, MyoG myogenin, $\beta$-Actin beta-actin

\section{Statistical analysis}

All data were analyzed using one-way analysis of variance followed by Tukey multiple test to compare means of all treatments. Significant differences were tested at $p<0.05$. Prior to data analysis, normality of data and homogeneity of variance were tested using Shapiro-Wilk normality test and Bartlett's test respectively. Graph Pad Prism (V.5.03) was used to perform all analysis data presented as mean \pm standard error of the mean (SEM).

\section{Results}

\section{Growth performance}

Effects of replacing fish oil with palm oil have been reported and discussed conclusively in Ayisi et al. (2018), a study directly related to this study. Additional file 1: Table S1 briefly shows how replacing palm oil with fish oil affected growth and feed utilization. Feed intake and condition factor were not significantly different among all treatments $(p>0.05)$. Final body weight and weight gain were however influenced by the experimental diets. Fish fed 50\% PO diet was significantly higher than in $25 \%$ PO but was non-significantly different from other groups $(p<0.05)$.

\section{Proximate composition of muscle}

The effects of replacing FO with PO on muscle proximate composition are shown in Table 4. Replacing FO with PO did not significantly influence muscle lipid, moisture, and ash. Moisture ranged from 742.9 to $748.3 \mathrm{~g} / \mathrm{kg}$, while lipid and ash ranged from 91.5 to 99.9 and 47.8 to $48.6 \mathrm{~g} / \mathrm{kg}$, respectively. Moisture content was modified by the inclusion of PO. Fish fed $25 \%$ PO recorded the least protein content $(672.6 \mathrm{~g} /$ $\mathrm{kg}$ ) and was significantly lower than fish fed $100 \%$ PO (760.0) $(p<0.05)$.

\section{Effect on muscle growth hormone (GH), Igf-I, Igf-II contents, and other growth-related enzyme activity} The effects of replacing FO with PO on growth-related enzyme activities are shown in Table 5. Pax-7 was significantly higher in fish fed 50\% PO than those fed 25\% $\mathrm{PO}$ and $100 \%$ PO $(p<0.05)$. Capn-3 in fish fed $0 \%$ PO was significantly lower than all other groups $(p<0.05)$. The highest value of MyoD was recorded in fish fed $50 \%$ PO and was significantly higher than groups fed $25 \%$ PO $(p<0.05)$. Fish fed 50\% PO recorded the highest IGF-I enzyme activity compared to fish fed $75 \%$ PO. Igf-II, $\mathrm{GH}, \mathrm{MyoG}$, and Psma- $\alpha 5$-were not significantly altered by dietary $\mathrm{PO}$ inclusion.

\section{Effect on mRNA expression of growth-related genes} The effects of replacing FO with PO on mRNA expression of growth-related genes are shown in Fig. 1. mRNA expression of Capn-3 of fish fed $75 \%$ PO was significantly higher $(p<0.05)$ than those fed 0\% PO, 25\% PO, and $100 \%$ PO with mean expression values ranging between 0.89 and 1.74. Also, fish fed 25\% PO downregulated Pax-7 mRNA expression which was significantly

Table 4 Muscle biochemical composition in Nile tilapia fed the experimental diets at 8 weeks

\begin{tabular}{|c|c|c|c|c|c|c|}
\hline \multirow{2}{*}{$\begin{array}{l}\text { Muscle } \\
\text { composition } \\
\text { (g/kg) }\end{array}$} & \multicolumn{5}{|c|}{ Experimental diets } & \multirow{2}{*}{$\begin{array}{l}p \\
\text { value }\end{array}$} \\
\hline & $\mathrm{PO} 0$ & PO 25 & PO 50 & PO 75 & PO 100 & \\
\hline Moisture & $742.9 \pm 13.5$ & $743.7 \pm 10.3$ & $746.4 \pm 1.40$ & $748.3 \pm 19.0$ & $744.3 \pm 33.0$ & 0.3338 \\
\hline Protein & $692.2 \pm 43.3^{\mathrm{ab}}$ & $672.6 \pm 13.6^{a}$ & $696.6 \pm 10.0^{\mathrm{ab}}$ & $749.1 \pm 16.5^{\mathrm{ab}}$ & $760.0 \pm 4.6^{\mathrm{b}}$ & 0.0182 \\
\hline Lipid & $94.8 \pm 1.2$ & $98.2 \pm 3.8$ & $95.4 \pm 0.5$ & $98.9 \pm 7.4$ & $91.5 \pm 0.8$ & 0.1073 \\
\hline Ash & $47.8 \pm 0.9$ & $48.2 \pm 4.3$ & $48.1 \pm 2.5$ & $47.9 \pm 2.9$ & $48.6 \pm 6.2$ & 0.4071 \\
\hline
\end{tabular}

Values are mean $\pm \operatorname{SEM}(n=3)$. Means not bearing the same superscript letters in the same row are significantly different $(p<0.05)$ 
Table 5 Muscle growth hormone, Igf-I, Igf-II contents, and other growth-related enzyme activity in Nile tilapia fed experimental diets at 8 weeks

\begin{tabular}{|c|c|c|c|c|c|c|}
\hline \multirow[t]{2}{*}{ Enzymes/genes } & \multicolumn{5}{|c|}{ Experimental diets } & \multirow[t]{2}{*}{$p$ value } \\
\hline & $\mathrm{PO} 0$ & PO 25 & PO 50 & PO75 & PO 100 & \\
\hline$\overline{P a x-7 ~(p g / m l)}$ & $791 \pm 52.67^{\mathrm{abc}}$ & $705.7 \pm 43.75^{a}$ & $947.80 \pm 16.05^{c}$ & $916 \pm 53.03^{b c}$ & $742.90 \pm 59.53^{\mathrm{ab}}$ & 0.0054 \\
\hline $\mathrm{GH}(\mathrm{ng} / \mathrm{ml})$ & $36.2 \pm 0.04$ & $35.9 \pm 0.03$ & $36.6 \pm 0.01$ & $36.1 \pm 0.01$ & $35.9 \pm 0.02$ & 0.0162 \\
\hline lgf-l (ng/ml) & $37.05 \pm 4.87^{\mathrm{ab}}$ & $28.06 \pm 0.05^{\mathrm{ab}}$ & $46.08 \pm 2.11^{b}$ & $24.40 \pm 0.39^{a}$ & $44.67 \pm 2.70^{\mathrm{ab}}$ & 0.4216 \\
\hline lgf-II (ng/ml) & $48.70 \pm 5.26$ & $58.61 \pm 1.70$ & $52.72 \pm 3.82$ & $53.92 \pm 1.61$ & $51.88 \pm 3.96$ & 0.4409 \\
\hline Psma a-5 (ng/ml) & $109.70 \pm 5.50$ & $120.10 \pm 7.97$ & $112.70 \pm 5.31$ & $119.2 \pm 8.06$ & $111.20 \pm 7.57$ & 0.7614 \\
\hline Capn-3(pg/ml) & $178.50 \pm 3.28^{a}$ & $233.20 \pm 9.66^{b}$ & $273 \pm 13.52^{\mathrm{b}}$ & $248.40 \pm 9.11^{b}$ & $245.6 \pm 14.23^{b}$ & 0.0001 \\
\hline MyoD (pg/ml) & $323.5 \pm 20.17^{\mathrm{ab}}$ & $272.9 \pm 19.04^{a}$ & $329.40 \pm 15.30^{b}$ & $281.60 \pm 16.70^{\mathrm{ab}}$ & $327.90 \pm 25.85^{b}$ & 0.0058 \\
\hline MyoG (pg/ml) & $534.80 \pm 14.46$ & $586 \pm 25.25$ & $560.10 \pm 43.44$ & $563.5 \pm 23.79$ & $535.01 \pm 23.79$ & 0.7246 \\
\hline
\end{tabular}

Pax-7 paired box protein 7, Igf-I insulin-like growth factor-I, Igf-Il insulin-like growth factor-II, GH growth hormone, Psma-a 5 proteasome subunit alpha type-5, Capn-3 caplain-3, MyoD myoblast determination protein, MyoG myogenin

Values are mean \pm SEM $(n=3)$. Means not bearing the same superscript letters in the same row are significantly different $(p<0.05)$

lower than all other groups $(p<0.05)$. The mean expression level of Pax-7 mRNA expression ranged between 0.33 and 1.35. There were no significant differences in the mRNA expression of Psma-5, MyoG, MyoD, Igf-I, Igf-II, and $\mathrm{GH}$ with mean expression values ranging between $1.00-1.16,1.04-1.24,1.00-1.27,1.07-1.33$, $1.01-1.16$, and $1.00-1.35$, respectively.

\section{Muscle fatty acid composition}

The effects of replacing fish oil with palm oil on muscle fatty acid have been reported by Ayisi and Zhao 2017. In brief, 18:3n-3 (LNA) and 20:4n-3 significantly increased with increasing PO inclusion levels $(p<0.05)$ while 20: 5n-3 (EPA), 20:4n-6 (ARA), and 22:6n-3 (DHA) decreased with increasing $\mathrm{PO}$ inclusion levels. Also, n-3 PUFA decreased while total saturated fatty acid (SFA) increased as PO inclusion levels increased $(p<0.05)$. The effect on muscle fatty acid composition is presented in Additional file 2: Table S2.

\section{Correlation between selected fatty acids, muscle lipid, and protein with mRNA expression of growth-related genes}

Correlation analysis between/of selected fatty acids, muscle lipid, and protein with mRNA expression is shown in Table 6. mRNA expression of Capn-3 and Psma- $\alpha 5$ was correlated positively with C18:3n-3(LNA) and C16:1n-9, respectively $(R=0.858, p=0.05$ and $R=0.88, p=0.045$ respectively). Also, Psma- $\alpha 5$ correlated positively with total MUFA $(R=0.986, p=0.002)$. Pax-7 correlated with C18: 2n-6 (LA) negatively $(R=-0.938, p=0.019)$ while GH correlated with $n-3 / n-6$ positively $(R=0.926, p=0.024)$. In addition, there was a negative correlation between Igf-I and C14:0, and C16:3n-3 and n-3 fatty acids $(R=-0.953, p=$ 0.012 ; $R=-0.879, p=0.049$; and $R=-0.864, p=0.05$ respectively). C20:4n-3 on the other hand correlated positively with IGF-I $(R=0.878, p=0.05)$. There was a positive correlation between Igf-II and C18:1n-9 $(R=0.898, p=$ $0.038)$ as well as SFA/PUFA $(R=0.886, p=0.049)$. There was negative correlation between Igf-II and C14:0 $(R=-0.886, p=0.045), \mathrm{C} 20: 0 \quad(R=-0.897, p=0.039)$, C16:3n-3 $(R=-0.893, p=0.041)$, and C20:5n-3 (EPA) $(R=-0.967, p=0.007)$. Also, C22:6n-3 (DHA), PUFA, total $\mathrm{n}-3$, and $\mathrm{n}-3 / \mathrm{n}-6$ ratio had negative correlation with Igf-II $(R=-0.994, p=0.001 ; R=-0.879, p=0.005$; $R=-0.994, p=0.001$; and $R=-0.910, p=0.032$, respectively). MyoG correlated negatively $(R=-0.885, p=0.04)$ with muscle lipid content while Igf-II correlated positively $(R=0.926, p=0.024)$ with muscle protein content.

\section{Discussions}

Results of the proximate composition of the muscle show that, with the exception of protein content $(p<$ $0.05)$, there were no significant differences among treatments for moisture, ash, and lipid. The non-significant difference observed in the lipid content of this study is in agreement to the results of Nanton et al. (2007) in which substituting FO with VO did not significantly influence muscle lipid content in salmon. Similarly, Asdari et al. (2011) reported a non-significant difference in moisture and ash content of Pangasius nasutus muscle when FO was substituted with soybean oil, palm oil, and linseed oil of which our results confirm. Growth in fish to some extent is largely dependent upon the accumulation of protein in skeletal muscle (Bureau et al. 2006). Fish fed 25\% PO recorded the least protein content in the muscle and correlated with its least growth performance. This could imply feeding fish with $25 \%$ PO might have degraded protein which is central to differences in growth response. In addition to the above, the differences that occur in muscle growth of fish are usually as a result of biological phenomenon which includes interactions between endogenous hormonal/genetic factors and external factors (Asaduzzaman et al. 2017). It is 


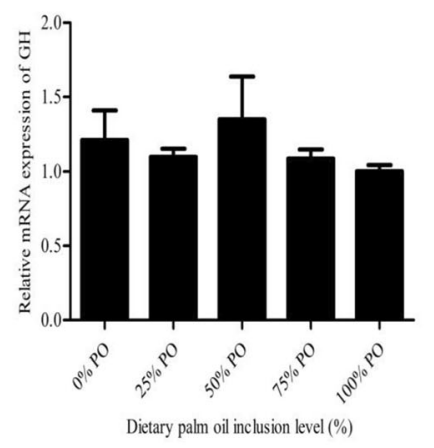

A

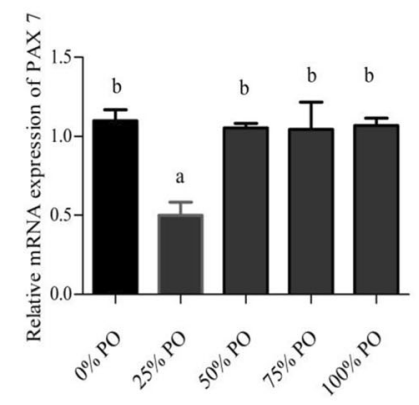

Dietary palm oil inclusion level (\%)

C

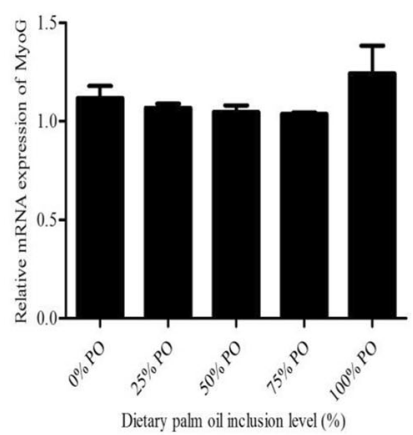

E

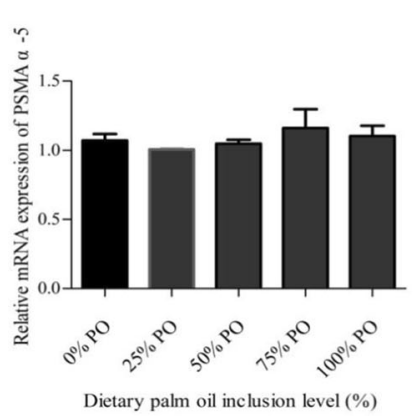

G

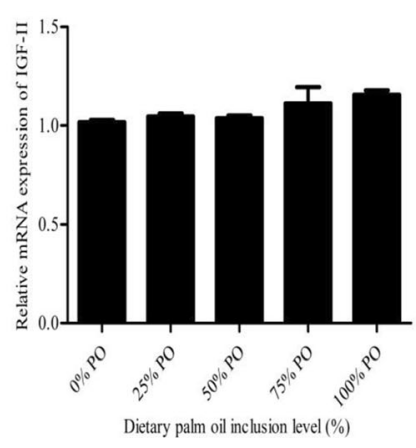

B

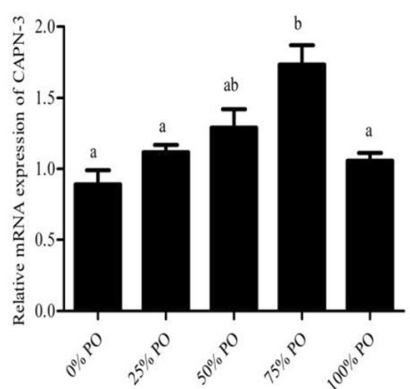

Dietary palm oil inclusion level (\%)

D

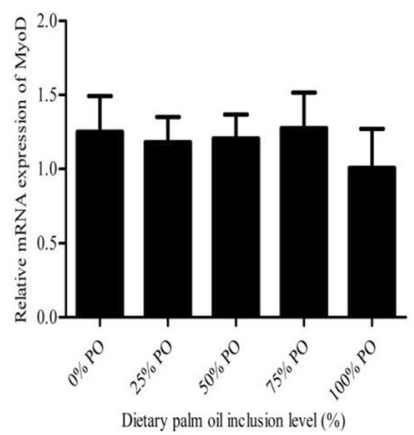

F

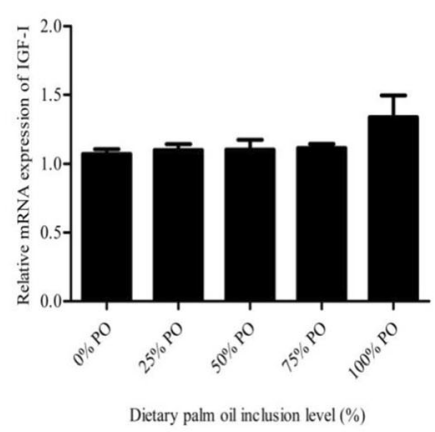

$\mathrm{H}$

Fig. 1 (See legend on next page.) 
(See figure on previous page.)

Fig. 1 Real-time PCR gene expression profiles of $\mathbf{A}$ growth hormone (GH), B insulin-like growth factor-II (Igf-II), C paired box protein (Pax-7), D caplain-3 (Capn-3), E myogenin (MyoG), F myoblast determination protein (MyoD), G proteasome subunit alpha type-5 (Psma-a5), and $\mathbf{H}$ insulinlike growth factor-I (Igf-I) in muscle of $O$. niloticus juvenile fed diets with different levels of palm oil (PO) for 8 weeks. Values are expressed relative to $\beta$-actin and are mean $\pm \operatorname{SEM}(n=3)$. Means not bearing the same superscript letters are significantly different $(p<0.05)$

therefore important to study the effects of replacing fish oil with palm oil on genes that regulate growth.

O. niloticus fed $25 \%$ PO recorded the least level of Pax-7 enzyme activity and was significantly lower than groups fed 50\% PO and 75\% PO. Also, this same group (25\% PO) downregulated mRNA expression of Pax-7 compared to all other groups and could imply feeding $O$. niloticus with 25\% PO could hinder muscle cell proliferation indicating Pax-7 plays an essential role in the specification of the muscle progenitor cells during hyperplastic muscle growth of fish (Kacperczyk et al. 2009).

The non-significant differences in mRNA expression and enzyme activities among groups recorded in this study are in agreement to an earlier study in Senegalese

Table 6 Correlations among growth-related gene expression values and relevant muscle fatty acids, lipid, protein, and wg, fcr, and sgr

\begin{tabular}{|c|c|c|c|}
\hline Genes & Fas & Pearson $R$ & $\overline{p \text { value }}$ \\
\hline Pax- & 18:2(n-6) (LA) & -0.938 & 0.019 \\
\hline $\mathrm{GH}$ & $n-3 / n-6$ & 0.926 & 0.024 \\
\hline Psma-a5 & $16: 1(n-9)$ & 0.887 & 0.045 \\
\hline Psma-a5 & MUFA & 0.986 & 0.002 \\
\hline Capn-3 & 18:3(n-3) (LNA) & 0.858 & 0.050 \\
\hline Igf-I & $14: 0$ & -0.953 & 0.012 \\
\hline Igf-I & $16: 3 n-3$ & -0.879 & 0.049 \\
\hline Igf-I & $n-3$ & -0.864 & 0.050 \\
\hline Igf-I & $20: 4 n-3$ & 0.878 & 0.050 \\
\hline $\mid \operatorname{lgf}-\|$ & $14: 0$ & -0.886 & 0.045 \\
\hline$|\lg f-| \mid$ & $20: 0$ & -0.897 & 0.003 \\
\hline $\mid g f-\|$ & $18: 1(n-9)$ & 0.898 & 0.038 \\
\hline$|\lg f-| \mid$ & $16: 3(n-3)$ & -0.893 & 0.041 \\
\hline $\mid g f-\|$ & $20:(5 n-3)(E P A)$ & -0.967 & 0.007 \\
\hline$|\lg f-| \mid$ & $22:(6 n-3)(D H A)$ & -0.993 & 0.001 \\
\hline$|\operatorname{lgf}-| \mid$ & $n-3$ & -0.994 & 0.001 \\
\hline$|\operatorname{lgf}-| \mid$ & PUFA & -0.879 & 0.005 \\
\hline $\mid \operatorname{lgf}-\|$ & SFA/PUFA & 0.886 & 0.049 \\
\hline $\mid g f-\|$ & $n-3 / n-6$ & -0.910 & 0.032 \\
\hline $\mid g f-\|$ & Protein & 0.926 & 0.024 \\
\hline MyoG & Lipid & -0.849 & 0.040 \\
\hline
\end{tabular}

Pax-7 paired box protein 7, Igf-I insulin-like growth factor-I, Igf-II insulin-like growth factor-II, GH growth hormone, Psma-a 5 proteasome subunit alpha type-5, Capn-3 caplain-3, MyoD myoblast determination protein, MyoG myogenin, $L A$ linoleic acid, LNA linolenic, ARA arachidonic acid, EPA eicosapentaenoic acid, DHA docosahexaenoic acid, SFA saturated fatty acids, MUFA monounsaturated fatty acid, PUFA polyunsaturated fatty acid sole (Campos et al. 2010). MyoD primarily control how myoblast are differentiated into skeletal muscle; hence, the reduction of MyoD enzyme activity in fish fed 25\% PO might have been an attributing factor that led to the lowest growth rate recorded in this group. In principle, increase in MyoD mRNA expression or enzyme activity could be related to intense satellite proliferation. Also, reduced or lower expression levels or enzyme activities could be related to low muscle growth rate and increased muscle catabolism and can be confirmed by low protein content in the muscle and its lower weight gain.

Several studies have used Igf and GH to infer and predict growth performance in fish subject to numerous biotic and abiotic factors that affect growth. This is because, through the growth hormone-insulin-like growth factor axis, the endocrine system controls growth in fish as well as other vertebrates (Picha et al. 2008). It also provides an integral signal for growth and nutrient partitioning and is also involved in tissue differentiation, metabolism, reproduction, behavior, and immunity. In this study, mRNA expression of GH was upregulated in fish fed $50 \%$ PO. It was, however, not significantly different from groups fed 0\% PO, 25\% PO, 75\% PO, but 100\% PO. Also, mRNA expression of IGF-I and IGF-II were indifferent irrespective of dietary PO inclusion levels. Feeding Senegalese sole with different lipid levels did not influence mRNA expression of both IGF-I and IGFII in the muscle (Campos et al. 2010) and is in agreement with our results.

To have an understanding of how muscle fatty acids, lipid, and protein contents influence growth-related genes, Pearson's correlation was used. IGF-I and IGF-II seem to be controlled by the quantity of $n-3$ PUFA available in both feed and muscle. This is because n-3 PUFA correlated significantly with IGF-I and IGF-II. As n-3 PUFA decreased in both muscle and feed, IGF-I and IGF-II increased even though there were no significant differences as in the case of the muscle n-3 PUFA.

DHA and EPA are essential for the growth of tilapia since they cannot be synthesized by tilapia. This study reported a strong negative correlation between Igf-II and DHA as well as EPA. This signifies that diets deficient in both EPA and DHA hinder the growth of muscle.

\section{Conclusion}

In conclusion, enzymes that are responsible for hypertrophy and hyperplasia (Pax-7, MyoD, and Capn-3) can be manipulated by replacing fish oil with palm oil in diet 
formulation. However, mRNA expression and enzyme activities show no correlation and might not affect the growth performance. This study provides essential information and an in-depth understanding of the function of growth-related genes at the translational level. In the future, it is important to study the changes of gene expression over a period of time as the patterns will change along the lifespan of fish.

\section{Supplementary information}

Supplementary information accompanies this paper at https://doi.org/10. 1186/s41240-019-0139-y.

Additional file 1. Table S1. Effects of replacing fish oil with palm oil on growth and feed utilization.

Additional file 2. Table S2. Fatty acid composition of muscle in nile tilapia fed experimental at 8 weeks $(\mathrm{g} / \mathrm{kg})$.

\section{Abbreviations \\ ARA: Arachidonic acid; CAPN-3: Caplain-3; DHA: Docosahexaenoic acid; ELISA: Enzyme-linked immunosorbent assay; EPA: Eicosapentaenoic acid; FO: Fish oil; GH: Growth hormone; Igf-I: Insulin-like growth factor-l; Igf- II: Insulin-like growth factor-II; LA: Linoleic acid; LNA: Linolenic; MUFA: Monounsaturated fatty acid; MyoD: Myoblast determination protein; MyoG: Myogenin; PAX 7: Paired box protein 7; PO: Palm oil; Psma-a 5: Proteasome subunit alpha type-5; PUFA: Polyunsaturated fatty acid; SFA: Saturated fatty acids; $\beta$-Actin: Beta-actin}

\section{Acknowledgements}

The authors are grateful to the students in Zhao Jinliang's laboratory for their assistance during sampling.

\section{Authors' contributions}

The study was designed by CLA and JZ. Feeding of fish was performed by $C L A$, and laboratory analysis was conducted by CLA, CY, and AA. Statistical analysis was performed by CLA and AA. The manuscript was written by CLA and GD. All authors read and approved the final manuscript.

\section{Funding}

This study received financial assistance from the China Agriculture Research System (CARS-46) and Shanghai Collaborate Innovation Center for Aquatic Animal Genetics and Breeding (ZF1206). The funders had no role in the study design, data collection and analysis, decision to publish, or preparation of the manuscript.

\section{Availability of data and materials}

All relevant data are within the paper.

\section{Ethics approval and consent to participate}

The present study was performed in strict accordance with the Standard Operation Procedures (SOPs) of the Guide for the Use of Experimental Animals of Shanghai Ocean University. All animal care and use procedures were approved by the Institutional Animal Care and Use Committee of Shanghai Ocean University. Fish were anesthetized with excess tricaine methane sulfonate (MS-222 at $200 \mathrm{mg} / \mathrm{L}$ ) before sampling in order to reduce suffering and stress.

\section{Consent for publication}

Not applicable.

\section{Competing interests}

The authors declare that they have no competing interests.

\section{Author details}

'Key Laboratory of Freshwater Fishery Germplasm Resources, Ministry of Agriculture, Shanghai Ocean University, 999 Huchenghuan Road, Shanghai 201306, China. ${ }^{2}$ Centre for Research on Environmental Ecology and Fish
Nutrition, Ministry of Agriculture, Shanghai Ocean University, Shanghai, China. ${ }^{3}$ National Demonstration Centre for Experimental Fisheries Science Education, Shanghai Ocean University, Shanghai, China. ${ }^{4}$ Faculty of Natural Resources and Environment, Department of Fisheries and Aquatic Resources Management, University for Development Studies, Tamale, Ghana. ${ }^{5} \mathrm{CAL}$ Aquaculture Research and Training Centre, P. O. Box 2, Adukrom-Akuapem, Eastern Region, Ghana.

Received: 5 June 2019 Accepted: 1 October 2019

Published online: 21 November 2019

\section{References}

American Public Health Association (APHA). Standard methods for the examination of water and wastewater. Washington, D.C: American Public Health Association; 1998.

Apraku A, Liu L, Leng X, Rupia EJ, Ayisi CL. Evaluation of blended virgin coconut oil and fish oil on growth performance and resistance to Streptococcus iniae challenge of Nile tilapia (Oreochromis niloticus). Egypt J Basic Appl Sci. 2017; 4(3):175-84.

Asaduzzaman M, Kader MA, Bulbul M, Abol-Munafi AB, Ghaffer MA, Verdegem ML. Biochemical composition and growth performances of Malaysian Mahseer Tor tambroides larvae fed with live and formulated feeds in indoor nursery rearing system. Aquac Nutr. 2017;4:156-63.

Asaduzzaman M, Kinoshita S, Bhuiyan SS, Asakawa S, Watabe S. Multiple ciselements in the $5^{\prime}$-flanking region of embryonic/larval fast-type of the myosin heavy chain gene, MYHM743-2, of torafugu function in the transcriptional regulation of its expression. Gene. 2011;489:41-54.

Asdari R, Aliyu-Paiko M, Hashim R. Effects of different dietary lipid sources in the diet for Pangasius nasutus (Bleeker, 1863) juveniles on growth performance, feed efficiency, body indices and muscle and liver fatty acid compositions. Aquac Nutr. 2011:17:e883-e891.35.

Ayisi CL, Zhao JL. Fatty acid composition, lipogenic enzyme activities and mRna expression of genes involved in the lipid metabolism of Nile tilapia fed with palm oil. Turk J Fish Aquat Sci. 2017;17:405-15.

Ayisi CL, Zhao JL, Rupia EJ. Growth performance, feed utilization, body and fatty acid composition of Nile tilapia (Oreochromis niloticus) fed diets containing elevated levels of palm oil. Aquaculture and Fisheries. 2017:2:67-77.

Ayisi CL, Zhao JL, Wu JW. Replacement of fish oil with palm oil: Effects on growth performance, innate immune response, antioxidant capacity and disease resistance in Nile tilapia (Oreochromis niloticus). PLOS ONE. 2018;13(4): e0196100. https://doi.org/10.1371/journal.pone.0196100.

Bureau DP, Hua K, Cho CY. Effect of feeding level on growth and nutrient deposition in rainbow trout (Oncorhynchus mykiss) growing from 150 to 600 g. Aquac Res. 2006;37:1090-98.

Campos C, Valente LMP, Borges P, Bizuayehu T, Fernandes JMO. Dietary lipid levels have a remarkable impact on the expression of growth-related genes in Senegalese sole (Solea senegalensis Kaup). J Exp Biol. 2010;213:200-9.

Duan C. Nutritional and developmental regulation of insulin-like growth factors in fish. J Nutr. 1998;128:3065-14S.

Duan C, Ren H, Gao S. Insulin-like growth factors (IGFs), IGF receptors, and IGFbinding proteins: roles in skeletal muscle growth and differentiation. Gen Comp Endocrinol. 2010;167:344-51.

Folch J, Lees M, Stanley GHS. A simple method for the isolation and purification of total lipids from animal tissues. J biol chem. 1957:226:497-509.

Gao W, Liu YJ, Tian LX, Mai KS, Liang GY, Yang HJ, Huai MY, Luo WJ. Proteinsparing capability of dietary lipid in herbivorous and omnivorous freshwater finfish: a comparative case study on grass carp (Ctenopharyngodon idella) and tilapia (Oreochromis niloticus $\times$ O. aureus). Aquac Nutr. 2011;17:2-12.

Johansen KA, Overturf K. Alterations in expression of genes associated with muscle metabolism and growth during nutritional restriction and re-feeding in rainbow trout. Comp Biochem Physiol Part B. 2006;144:119-27.

Johnston IA, Macqueen DJ, Watabe S. Molecular biotechnology of development and growth in fish muscle. In: Tsukamoto K, Kawamura T, Takeuchi T, Beard Jr TD, Kaiser MJ, editors. Fisheries for Global Welfare and Environment, $5^{\text {th }}$ World Fisheries Congress. Tokyo: TERRAPUB; 2008. p. 241-62.

Kacperczyk A, Jagla T, Daczewska M. Pax-3 and Pax-7 label muscle progenitor cells during myotomal Myogenesis in Coregonus lavaretus (Teleostei: Coregonidae). Anat Histol Embryol. 2009;38:411-8.

Li Y, Gao J, Huang SQ. Effects of different dietary phospholipid levels on growth performance, fatty acid composition, PPAR gene expressions and antioxidant 
responses of blunt snout bream Megalobrama amblycephala fingerlings. Fish Physiol Biochem. 2015;41:423-6.

Li Y., Liang X, Zhang Y, Gao J. Effects of different dietary soybean oil levels on growth, lipid deposition, tissue fatty acid composition and hepatic lipid metabolism related gene expression in blunt snout bream (Megalobrama amblycephala) juvenile. Aquaculture. 2016:451:16-23.

Menoyo D, Lopez-Bote CJ, Obach A, Butista JM. Effects of dietary fish oil substitution with linseed oil on the performance, tissue fatty acid profile, metabolism, and oxidative stability of Atlantic salmon. J Animal Nutr. 2005;92:41-52.

Nanton DA, Vegusdal A, Rørå AMB, Ruyter B, Baeverfjord G, Torstensen BE. Muscle lipid storage pattern, composition, and adipocyte distribution in different parts of Atlantic salmon (Salmo salar) fed fish oil and vegetable oil. Aquaculture. 2007;265:230-43.

Picha ME, Turano MJ, Tipsmark CK, Borski RJ. Regulation of endocrine and paracrine sources of Igfs and Gh receptor during compensatory growth in hybrid striped bass (Morone chrysops $\times$ Morone saxatilis). J Endocrinol. 2008;199:81-94.

Watabe S. Myogenic regulatory factors. Fish Physiol. 2001;24:19-41.

\section{Publisher's Note}

Springer Nature remains neutral with regard to jurisdictional claims in published maps and institutional affiliations.

Ready to submit your research? Choose BMC and benefit from:

- fast, convenient online submission

- thorough peer review by experienced researchers in your field

- rapid publication on acceptance

- support for research data, including large and complex data types

- gold Open Access which fosters wider collaboration and increased citations

- maximum visibility for your research: over $100 \mathrm{M}$ website views per year

At $\mathrm{BMC}$, research is always in progress.

Learn more biomedcentral.com/submissions 